Article

\title{
Augmented Reality and Mobile Devices: A Binominal Methodological Resource for Inclusive Education (SDG 4). An Example in Secondary Education
}

\author{
Francisco del Cerro Velázquez * (D) and Ginés Morales Méndez (1) \\ Energy Engineering and Teaching Innovation Research Group in Technology, Faculty of Education \\ (“C” Building), University of Murcia, Campus de Espinardo, 30100 Murcia, Spain; gines.morales@um.es \\ * Correspondence: fcerro@um.es; Tel.: +34-868-887-696
}

Received: 16 August 2018; Accepted: 25 September 2018; Published: 27 September 2018

check for updates

\begin{abstract}
The rise of so-called emerging technologies is broadening the way in which students access information and in turn changing the way in which they can interact and the experiences to which they are exposed. Mobile devices are regarded as flexible tools that facilitate access to information in different formats and in any environment. For its part, Augmented Reality is a technique that, through mobile tools, can enhance the globalization of content and access to contextual information in various ways. Together, the globalization of mobile devices and Augmented Reality contribute to an inclusive, equitable, and quality education, as mentioned by the United Nations Educational, Scientific, and Cultural Organization (UNESCO) in goal four on Sustainable Development (Sustainable Development Goals 4 (SDG 4)). This article analyses the binomial Augmented Reality-mobile devices, and takes a conceptual approach to these technological environments, both the technique and the tool, in the context of quality education. To assess the potential of Augmented Reality-mobile devices as a methodological learning resource, a learning unit of Secondary Education is presented in the field of Technology, enriched with different materials related with Augmented Reality.
\end{abstract}

Keywords: augmented reality; mobile devices; education for sustainable development; sustainable development goals; SDG 4

\section{Introduction}

Recent years have seen a deepening of reflection and debate on the universal right to a quality education that gives priority to children. To achieve this goal, education systems must improve in terms of access, resources, the quality of education processes, and, subsequently, of learning outcomes. In addition, it is necessary for education to be relevant and suited to the needs of receivers [1].

At the curricular level, relevance requires open and flexible designs that can be enriched or adapted at different levels, depending on the educational needs, aptitudes, and interests of students, and the characteristics and requirements of the contexts in which they develop and learn. As pointed out by the United Nations Educational, Scientific, and Cultural Organization (UNESCO) [2-5], making learning relevant to all requires a profound transformation of educational practices, transitioning from a pedagogy of homogeneity towards a pedagogy of diversity.

Also, the United Nations (UN) [6] and UNESCO [7,8] point out that the inequalities, stigmatization, and discrimination related to income level, gender, ethnicity, language, place of residence, and disability affect progress towards Education For All (EFA). Therefore, it is evident that at the heart of this discussion are the huge gaps that persist in educational systems that mainly affect groups and people traditionally excluded, for whom authors such as Thomazet [9] affirm that it is necessary to make 
efforts to achieve an inclusive education, because it belongs to the universe of ethics, social justice, deep democracy, and equality. Other authors $[10,11]$ add that exclusion rates should be significantly reduced even though it is difficult to reach full inclusion. However, the 2015 report of the Millennium Development Goals (MDGs) [12] described a worldwide reduction of half the number of children who are of primary school age that did not attend school, meaning that significant progress has been made with respect to the six goals of the EFA initiative established in 2000 and MDGs related to education $[2,13]$.

Continuing with the advances made in MDGs and in an attempt to overcome the numerous challenges to achieve EFA, the new Education Agenda 2030 [14], which forms part of the Sustainable Development Goals (SDG) adopted on September 2015 and, more specifically, the Education Action Framework 2030 approved in November 2015 at the 38th Session of the General Conference of UNESCO, point to the SDG 4 roadmap.

For its part, SDG 4 is broken down into 7 goals and 3 means of implementation, although its overall objective is: "to guarantee an inclusive, equitable and quality education and promote lifelong learning opportunities for all" $[15,16]$.

Therefore, we must move towards inclusive educational systems of diversity, emphasizing people's needs and access to education. The objective of the present study is, therefore, to look at the difficulties, opportunities, and progress achieved in incorporating Information and Communication Technology (ICT) in education, focusing on augmented learning environments and their potential inside the classroom through the use of mobile devices: that is, the importance of the binominal Augmented Reality (AR) and mobiles devices in sustainable development, and their contribution to an inclusive, equitable, and quality education marked by SDG 4 for the 2030 horizon.

\section{Materials and Methods}

First, a descriptive overview is made of AR and its characteristics as a methodological resource supported by mobile devices for the teaching-learning process for sustainable development. Following this, AR and mobile devices are empirically used to produce augmented materials for a learning unit, which, in our context, represents a series of contents and objectives in the technology area. Finally, the impact of incorporating these educational resources in the classroom is analyzed.

\subsection{The Binomial Augmented Reality and Mobile Devices as a Methodological Resource in Inclusive Education for Sustainable Development}

Augmented Reality or AR is a technique that consists of adding virtual information in a real scenario [17]. The definition of this term can be completed by saying that AR is a process that is performed in real time based on what a device captures and that establishes a spatial relationship between virtual information and real environment. Note at this point that when talking about added or virtual information layered over a real environment, we refer to any type of information that can be digitized, as is the case of texts, images, videos, audios, web links, three-dimensional (3D) models, etc. The essential elements necessary to be able to visualize content in AR are a computer or a mobile device incorporating a camera and a program or application that executes and interprets the AR. Currently there are two accepted definitions of AR:

(i) In 1994 Paul Milgram and Fumio Kishino [18] defined a continuous scale that goes from the real environment to the virtual environment, called the Reality-Virtuality Continuum. The area between the two extremes, where the "Real Environment" and the "Virtual Environment" combine, is called "Mixed Reality", as shown in Figure 1. Within this scale, "Augmented Reality" can be distinguished as that which incorporates virtual elements in a real environment, while "Augmented Virtuality" incorporates real elements in a virtual environment.

(ii) In 1997, Ronald Azuma [19] determined that an AR system has to fulfill three fundamental characteristics: that it combines real and virtual elements, that it is interactive in real time, and that it is registered in $3 \mathrm{D}$. 


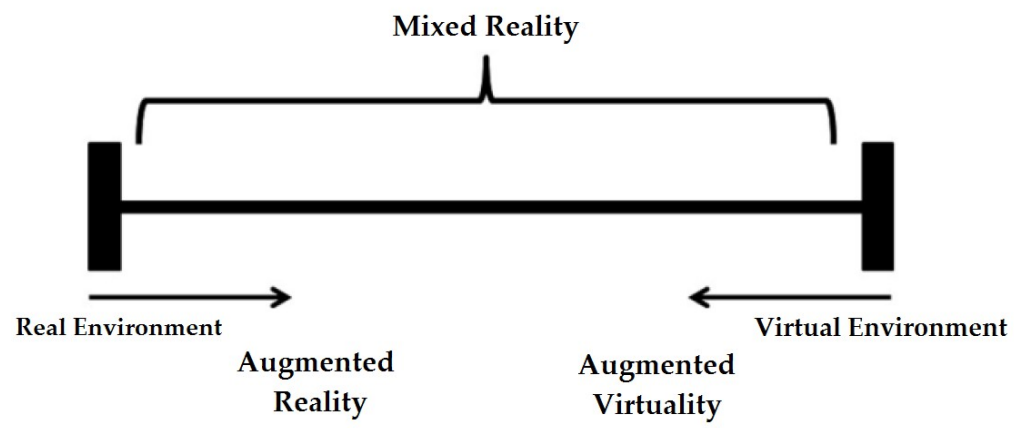

Figure 1. Reality-Virtuality Continuum [18].

Other authors define AR as a technology that makes it possible to generate virtual environments that overlap a real environment in a direct or indirect way, allowing the interaction of reality with the visualization of virtual graphics $[20,21]$. This means that the AR has the capacity to fill the gap between the real and the virtual world in a perfect way; this functionality is one of the main characteristics that enables this technique to be applied in a wide range of human activities, education being the most important [22,23].

Generally, the superposition of information on the real world is basically aimed at improving the perception that an individual has of the real world by initiating the creation of an interactive experience. Therefore, the fundamental objective of AR is to add more information, that is to say more meaning, to real objects or places [24-27], thus improving our understanding of the world that we are observing.

For example, in the science classroom, the teacher can superimpose image data on the textbook that students can visualize through their mobile devices, enabling them to observe with a high level of detail resources that are not generally available in the classroom, such as a turbo generator in a class dealing with energy and its transformation. Similarly, AR may include location data, audio comments, historical contexts, and other forms of content that make a user's experience more meaningful, immersing them in a more intense learning environment $[28,29]$.

The potential of AR in education was identified almost from its inception-a system that allows the user in the classroom to manipulate 3D objects and receive information from a real environment is clearly of great relevance in the educational field $[19,30]$.

In addition to addressing issues such as those already discussed above, this technology has made it possible for both teachers and students to see information in a real environment that would otherwise be impossible to show, allowing many scientific concepts to be visualized that until now were impossible to illustrate clearly.

The methods used with AR technology in education are usually linked to textbooks and material generated by the teacher, using tools such as computers and/or mobile devices [30].

$\mathrm{AR}$ does not only make the teaching-learning processes simpler, but also makes them more interesting and motivating. Indeed, one of its most frequent uses in education is to complement textbook material or that written and prepared by the teacher. In this sense, there are studies [31] that affirm that students continue to prefer the real book to digital supports because of the advantages they have (ease of transport, robustness, etc.). However, it is still possible to increase and improve these written materials through AR, offering new possibilities for interaction both inside and outside the classroom.

One of the first educational experiences where this technology was incorporated was the Magic Book [32], where by AR was used to complement the content through the superposition of a virtual content and 3D animations. This augmented book had all the physical characteristics of an ordinary book with the advantage that, through AR, the written story could be represented in a three-dimensional space located on marks or images of the pages, corresponding to the scale established by the authors in Figure 2. 


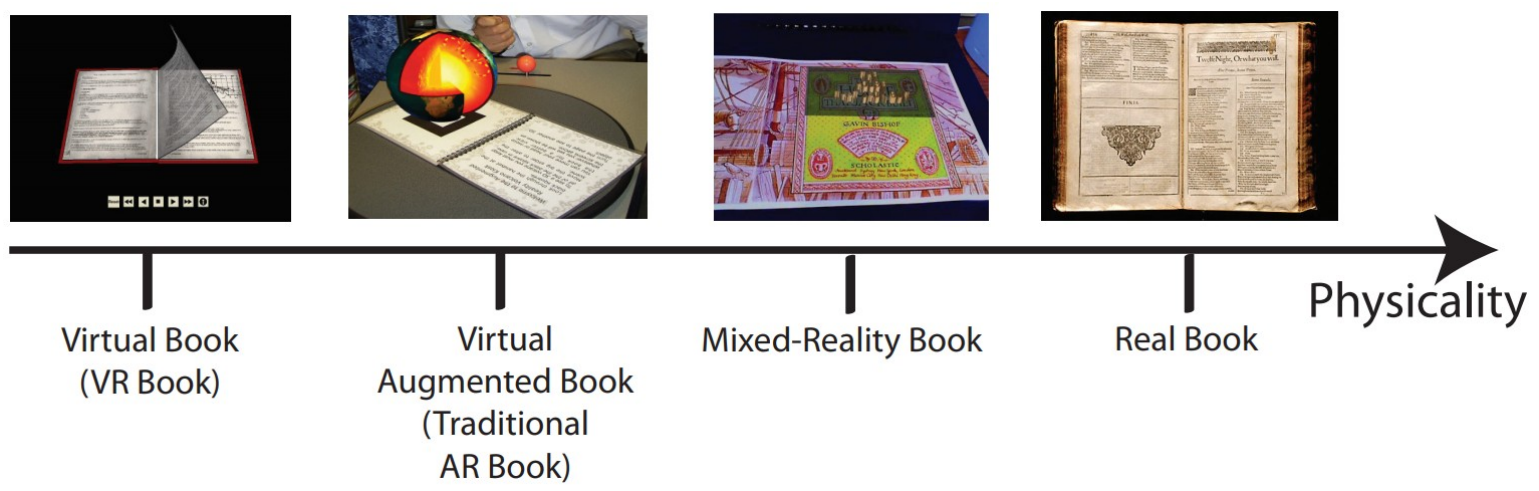

Figure 2. Virtuality-Reality Book Continuum [32].

AR is able to provide the student with contextual learning experiences by providing the possibility to explore and discover the augmented real world with previously inaccessible added information [33]. The educational experience based on AR can be considered far from traditional teaching methods because of the following fundamental characteristics:

(i) Collaborative Capacity: the interaction-collaboration relationship among students is one of the primary objectives of any educational environment [34,35]. In this aspect, AR will increase the collaborative capacity of the classroom by enabling multiple users to access a shared space of virtual resources. This characteristic is especially important for any educational level, since it allows students to effectively combine numerous ICT tools through AR technology. This system of collaborative work can be further enhanced by integrating services hosting these multimedia resources in the cloud, such Google Drive, Google Classroom, Dropbox, OneDrive, etc. In this way, material is shared and made fully available for use by educators and students, without the need to pay license fees. These resources for non-commercial purposes are known as Open Educational Resources (OER).

(ii) Continuous Interaction: from a traditional learning point of view, when two or more students work together in a common space, it becomes a space of communication. In this sense, by applying the appropriate technology we allow students to interact with the real world and the virtual world at the same time. During a master class, the focus is on the blackboard, digital or not; by applying AR technology attention goes beyond the collaborative work center, while the blackboard moves on to a different plane (that is not secondary) [36]. This is one of the pillars of the augmented learning environment, the union of educational technology with traditional resources such as the blackboard or textbook. In addition, by using tools such as mobile devices to carry out this type of activity within AR, students have access at all times and anywhere to these resources, which further accentuates the meaning of continuous interaction through the Mobile Learning or m-learning. The projects developed by UNESCO [37] have shown that mobile devices allow literacy, promote the motivation of students, and improve the possibilities of professional development of teachers and communication between parents and teachers.

(iii) Tangibility: generally, AR allows the manipulation of an object through the use of what is known as the Tangible Interface Metaphor [38]. The teaching-learning is improved when physical objects are used, because these objects are not only a representation for students, but also encourage proactive learning through their tangibility. The use and manipulation of physical objects, as well as their semantic representations and their spatial disposition, help students towards the comprehension and learning of certain content with high visual load. AR technology allows us to recreate virtually any physical object, and, through a tangible interface, we can manipulate it to obtain information about and from it, promoting proactive learning. Therefore, AR allows physical resources to be replaced by virtual objects, which represents an educational strategy of great potential for improving the teaching-learning process in any area and for any 
content, where spatial intelligence is necessary, such as Science, Technology, Engineering, Art, and Mathematics (STEAM) [30].

\subsection{Inclusive and Equitable Quality Education through AR and Mobile Devices}

In accordance with the objective or guiding principle of SDG 4 to "ensure inclusive, equitable and quality education and promote lifelong learning opportunities for all" [2-5], the prize "King Hamad Bin Isa Al Khalifa" [39] recognized ICT for its potential to contribute to educational equity and quality. Assessing the importance of ICT in education, the Director General of UNESCO, Audrey Azoulay, concluded in her closing speech to the 9th edition of the aforementioned prize in 2017, that we must transmit our values and exchange the most innovative and effective pedagogical practices to meet the challenge of quality and accessibility. Thus, if ICTs are also interactive and focus on the students through AR, they can become great allies for reaching the goals of SDG 4.

As regards educational diversity and the concept of accessibility regardless of technical, cognitive, or physical capacities, AR can improve and heighten the information provided. The reason for this is that AR converts learning situations into contextual situations, which can only improve educational praxis [40].

From the inclusive point of view, such contextual elements need not be exclusively based on information in the form of text, but may also be shown through sounds, videos, texts, images, 3D models, etc. In this way the augmented elements can be adapted so that people with functional limitations can access them. The technology should also be accessible, since accessibility is a right, not an option [41], and, as indicated above, AR allows access to contextual information in various ways. Therefore, it is important to incorporate contextual elements in the structural design of augmented applications for use in and outside the classroom that have the ability to enhance and increase the quality of learning by producing and distributing constructive content according to individual needs.

However, despite the potential of AR to favor formal and non-formal inclusive education, and despite being a technology with undoubted advantages for students and teachers, it has not yet been used to its full potential [24].

Another of the main reasons for implementing augmented technology in the field of education is to simplify the learning process. Through AR-based methodologies, a high degree of simplicity cam be achieved, since it allows the assimilation of knowledge and enhancement of skills associated with the visualization of and interaction with different types of digital content superimposed on reality.

Unfortunately, to apply AR in an inclusive environment we cannot simply depend on the undoubted advantages of this technology, and for the technique to be used by all, there are barriers that must be overcome, which may not always be possible.

In the first place, it has to be an affordable technology, which is the main obstacle, and the tools to use this technology are not always available. However, in terms of devices, the "democratization" of their use has made the technology much more accessible.

Indeed, the ubiquity of these devices is changing the way people interact with information and their environment. The continuous improvement in the hardware, accompanied by reductions in price enable students to access a variety of platforms, applications, and learning materials anywhere in the world. In fact, in 2016, the web traffic analysis tool StatCounter [42] reported that more than $50 \%$ of web browsing worldwide was done through smartphones and tablets, exceeding for the first time that done through computers. Moreover, the global mobile learning market is expected to grow by $36 \%$ annually, from 7.98 trillion dollars in 2015 to 37.6 trillion in 2020 [43].

Likewise, mobile devices have become access and entry portals to personalized Open Educational Resources OER, facilitating the learning of diverse matters at the rhythm of each user. As if this were not enough, students can also use mobile phones to put into practice the competencies of the 21st century, including communication, collaboration, and content creation. With all this in mind, the importance of the binomial AR-mobile devices in Sustainable Development for the 2030 horizon is evident. 
Although it is true that most educational centers in developing countries do not have the appropriate tools, facilities, or ICT resources to provide students with practical knowledge, it is no less true that even without economic investment in ICT resources, the global expansion in the use of smartphones will provide one of the most useful means for access to information. In short, our binomial should help ensure sustainable development for the 2030 horizon [2-5].

\subsection{The Augmented Reality and Mobile Devices Binomial in a Technology Learning Unit}

Among the principles of constructivist learning, the role of the teacher as mediator and guide during the process of acquisition and assimilation of knowledge is well known. Considered as the main means for the students' learning, teachers must constantly update their skills to construct appropriate teaching-learning spaces. According to this idea, the teacher has the possibility to introduce the most appropriate variety of content. In this sense, several authors maintain that materials and resources on the screen are the best way for students to understand or memorize since, through an image, students can get more information than from text or a theoretical explanation [44-47].

Reflecting what has been said about the creation or production of materials based on visualization, AR permits the written history in any book to be linked to a digital and/or three-dimensional space [48], which will surely become one of the main aims of publishers, i.e., to start presenting their complementary or support materials in AR (to date normally offered through a Digital Versatile Disc DVD attached to the textbook or digital licenses).

However, as indicated in the previous paragraph and taking into account that the teacher does not necessarily have to follow the textbook, the teachers can generate their own files linked to objects in AR. For this, it is clear that the teacher must have sufficient knowledge to design their own activity sheets or OER work materials in what Del Cerro and Morales [30] call the "Production of Augmented Materials" which should be systematic and sequential.

Subsequently, the work sheets can be read through the camera of a mobile device by means of an application (app). For this purpose, the software "layar" version 8.5 (Layar B.V., Amsterdam, Netherlands) has been used to design and link the digital content in AR (videos, interactive image galleries, 3D models, web links, etc.) through smartphones [49]. Here, by means of the technique "markerless" these are linked to the worksheets generated by the teacher for the learning unit "Energy and its transformation" (Figure 3).

Reading the above file through the application "layar" [49] generates three types of augmented materials: an explanatory video of the operation of a wind turbine, a map of the wind farms in Spain, and a 3D image of a wind turbine that the student can analyze with small turns or movements of his smartphone or tablet that generate different views or perspectives of the wind turbine in AR (Figure 4).

Having generated the worksheets, we turn to assessing the effects on learning after implementing the above augmented files in the Technology learning unit of the Technology subject. Specifically, two 3rd year classes of Obligatory Secondary Education (ESO) were assessed: Group 1 used the augmented material for learning, while Group 2 followed the usual classroom practice. 


\section{Energia eólica}

Es la energía producida por el viento. Su utilización a lo largo de la historia de la humanidad en los molinos de viento o en los barcos de vela nos da idea de su importancia en tiempos pasados.

En la actualidad, el aprovechamiento de la energía eólica se centra en el bombeo de agua de pozos y en la producción de energia eléctrica. La producción de energía eléctrica a partir de la fuerza del viento se realiza en las centrales eólicas. Estas instalaciones están formadas básicamente por un conjunto de aerogeneradores o molinos de viento.

Cuando el viento mueve las palas del aerogenerador, se produce un movimiento de rotación en el eje de la turbina. Un sistema de transmisión multiplica las vueltas del eje y, a la vez, transmite el movimiento de giro al eje del alternador, que genera energía eléctrica.

El aerogenerador, que está situado a una cierta altura del suelo, soportado por una torre, ha de estar constantemente orientado en dirección perpendicular al viento, cosa que se consigue con un sistema de orientación.

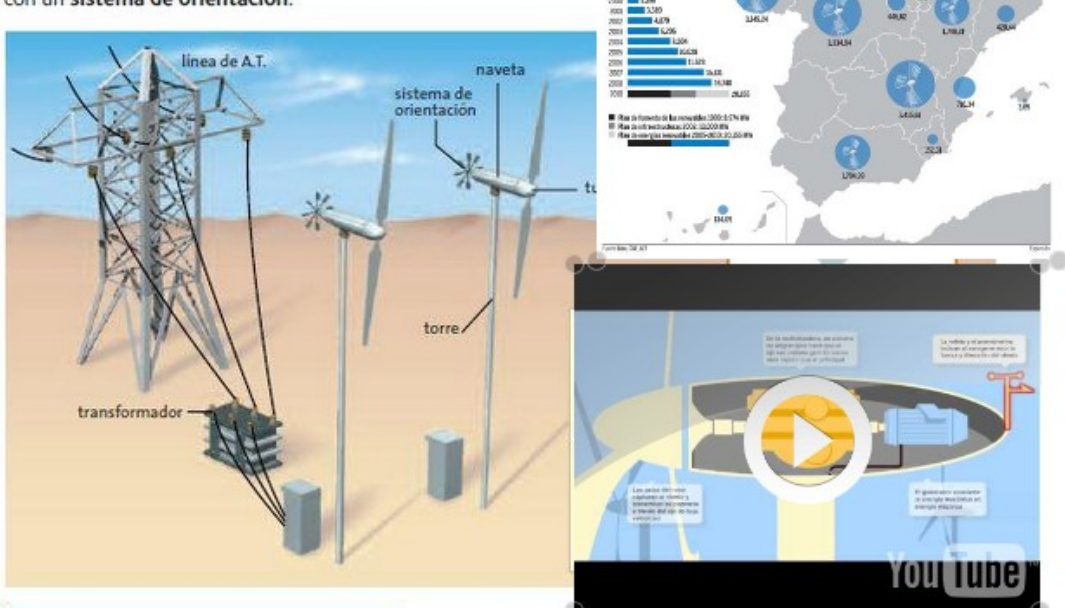

Figure 3. Worksheet with AR content.

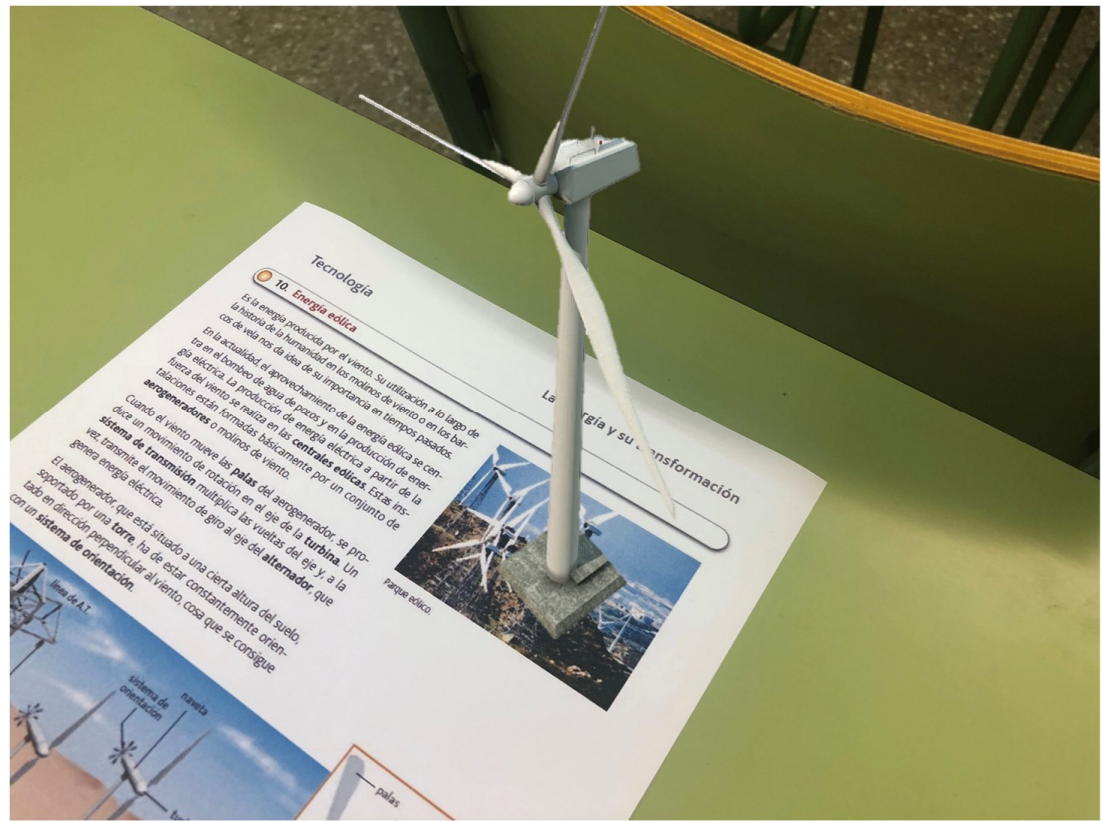

Figure 4. Three-dimensional (3D) wind turbine design in AR. 
The data collection tools used in the research are divided into three sections, as shown in Table 1.

Table 1. Data collection tools design and method.

\begin{tabular}{cc}
\hline Tool & Method \\
\hline Written Test Group 1 (with AR) & Each student is required to complete a written test independently \\
Written Test Group 2 (without AR) & Each student is required to complete a written test independently \\
Questionnaire Group 1 (with AR) & Each student completes a personal questionnaire \\
\hline
\end{tabular}

To assess the effect of the two methods, a $t$-test model was used to compare the averages of the two data samples, the null hypothesis " $\mathrm{H} 0$ " being that there would be no difference between the scores of the written test of groups 1 and 2, and the alternative hypothesis "H1" being that there would be a difference between the respective scores.

The written test taken by both groups was identical, and was based on the content taught in the learning unit and the normal evaluation standards.

At the end of the experiment, a Likert scale questionnaire was given to the students of group 1 to ascertain the perception of the students concerning their experience. The questionnaire focused mainly on the following points:

(i) The use of AR technology in the teaching-learning processes.

(ii) The contribution of AR tools to the better understanding of the content.

(iii) The difficulty of using AR tools and applications.

(iv) The memorization of content after implementing the AR techniques.

\subsection{Data Analysis}

The Statistical Package for the Social Sciences (SPSS) for Windows, version 24 (IBM Corp., Armonk, NY, USA) was used for the data analysis of the written tests and questionnaire. An independent $t$-test was performed on the scores obtained in the written tests of groups 1 and 2 to determine differences between them. Subsequently, descriptive statistical calculations were made for each item of the questionnaire, including the average score, the standard deviation, and the maximum and minimum values. In addition, the Pearson correlation coefficient was used to identify the difference in means between the two learning processes.

\section{Results}

The written test was carried out by 56 students (29 in group 1 and 27 in group 2), and all were considered valid for the study, Table 2. The maximum score for the written test was 10 points, the mean scores of groups 1 and 2 being 7.51 and 4.48, respectively meaning that group 1 showed an improvement of $67.63 \%$ over the average scores of group 2, as shown in Equation (1).

$$
\text { Improvement }(\%)=\frac{\text { Group } 1 \text { Mean }- \text { Group } 2 \text { Mean }}{\text { Group } 2 \text { Mean }} \times 100=\frac{7.51-4.48}{4.48}=67.63 \%
$$

Table 2. The $t$-test results on the scores obtained from the written tests of groups 1 and 2 .

\begin{tabular}{lccccccc}
\hline & N & Maximum & Minimum & Median & Media & Std. Deviation & Std. Error Mean \\
\hline Group 1 & 29 & 9.6 & 2.1 & 7.6 & 7.51 & 17.75842 & 3.723 \\
Group 2 & 27 & 7.2 & 1.8 & 4.1 & 4.48 & 15.69714 & 3.248 \\
\hline
\end{tabular}

Table 3 shows the results of the test for two independent samples. According to the results, the significance value of the Levene test was higher than 0.05 . Therefore, the variability in the two 
conditions was the same, which shows that the scores obtained by group 1 did not vary significantly compared with those of group 2. Therefore, a variance of equal value is assumed.

Table 3. Levene's Test and $t$-test results for the equality of means.

\begin{tabular}{|c|c|c|c|c|c|c|c|c|c|c|}
\hline & & \multicolumn{2}{|c|}{$\begin{array}{l}\text { Levene's Test for } \\
\text { Quality of } \\
\text { Variance }\end{array}$} & \multicolumn{7}{|c|}{$t$-Test for Equality of Means } \\
\hline & & \multirow[t]{2}{*}{$\mathbf{F}$} & \multirow[t]{2}{*}{ Sig. } & \multirow[t]{2}{*}{$\mathbf{t}$} & \multirow[t]{2}{*}{ df } & \multirow[t]{2}{*}{$\begin{array}{c}\text { Sig. } \\
\text { (2-Tailed) }\end{array}$} & \multirow[t]{2}{*}{$\begin{array}{c}\text { Mean } \\
\text { Difference }\end{array}$} & \multirow[t]{2}{*}{$\begin{array}{c}\text { Std. Error } \\
\text { Difference }\end{array}$} & \multicolumn{2}{|c|}{$\begin{array}{l}95 \% \text { Confidence } \\
\text { Interval of the } \\
\text { Difference }\end{array}$} \\
\hline & & & & & & & & & Lower & Upper \\
\hline \multirow{2}{*}{ Marks } & $\begin{array}{c}\text { Equal } \\
\text { variances } \\
\text { assumed }\end{array}$ & 0.058 & 0.842 & 4.392 & 52.014 & 0.000 & 3.03 & 4.697 & 1.152 & 3.084 \\
\hline & $\begin{array}{c}\text { Equal } \\
\text { variances } \\
\text { not assumed }\end{array}$ & & & 4.431 & 51.976 & 0.000 & 3.03 & 4.651 & 1.147 & 3.075 \\
\hline
\end{tabular}

Figure 5 shows the differences in the scores obtained by students using AR technology as a learning tool and those who had followed a traditional teaching method. The result show that $23.16 \%$ of the students who used AR obtained 4-6 in the test, while $26.14 \%$ of those exposed to traditional teaching fell in the same range of scores. However, $42.76 \%$ of students scored between 6 and 8 with AR, while only $28.13 \%$ of students following the traditional teaching method fell within this range. With AR, $28.2 \%$ of the students achieved grades between 8 and 10, whereas no student following the traditional teaching method obtained such a high score. In other words, the number of students who scored higher than 6 in the written test was significantly higher in the AR group of students. Of particular note is the difference between the numbers of students from both groups who obtained the highest range of scores.

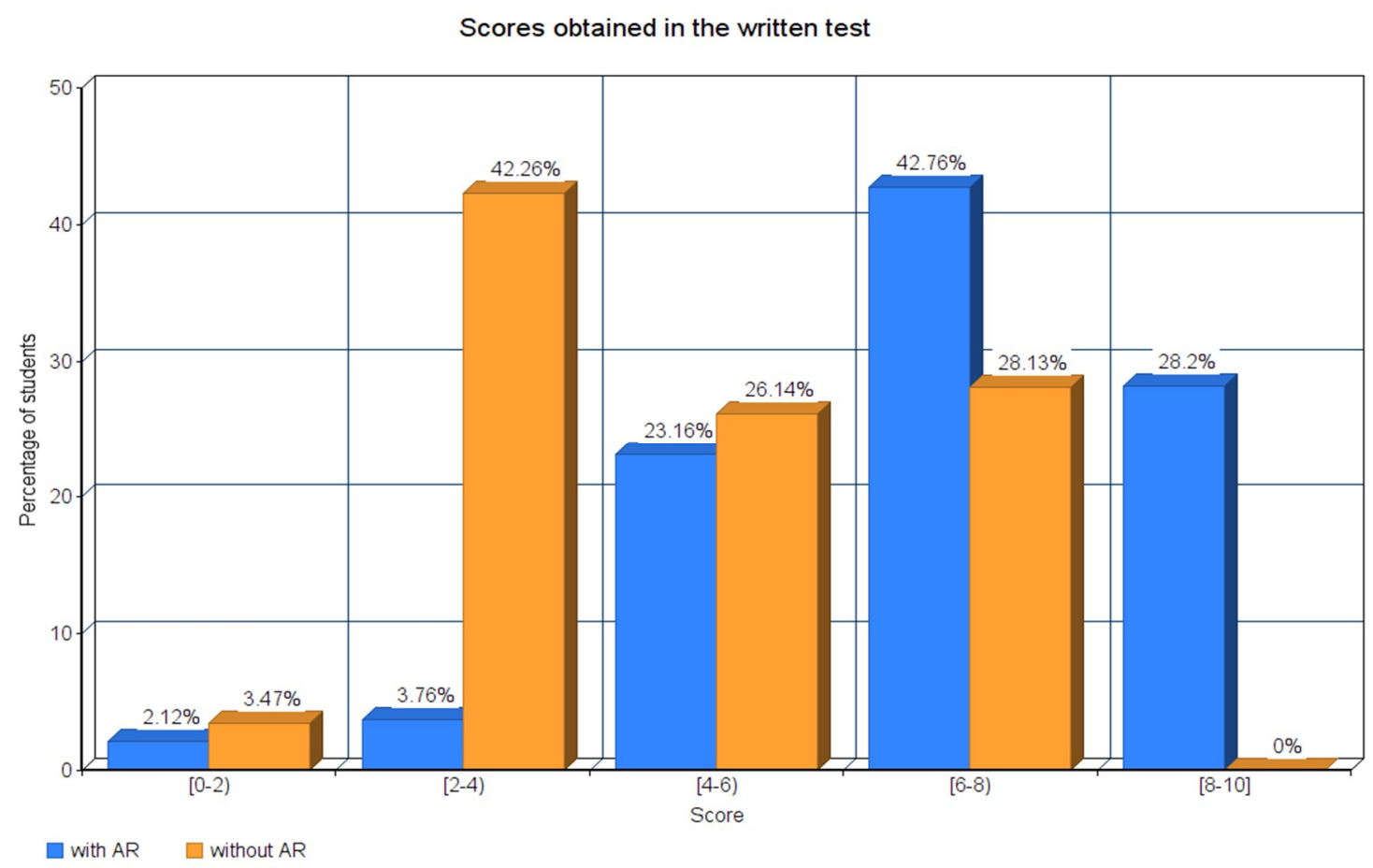

Figure 5. Scores obtained in the written test through AR and without AR.

As regards the data obtained from a Likert scale questionnaire, more than $56.92 \%$ of the students said they very interested in using of AR as a teaching tool (Figure $6 \mathrm{a}$ ), and $27.84 \%$ of students said they were satisfied with using AR for content learning. No student disagreed or strongly disagreed with 
the use of this learning tool. These results reveal the high predisposition of students to use AR tools in the classroom and their motivation.

Interest of students in learning through AR

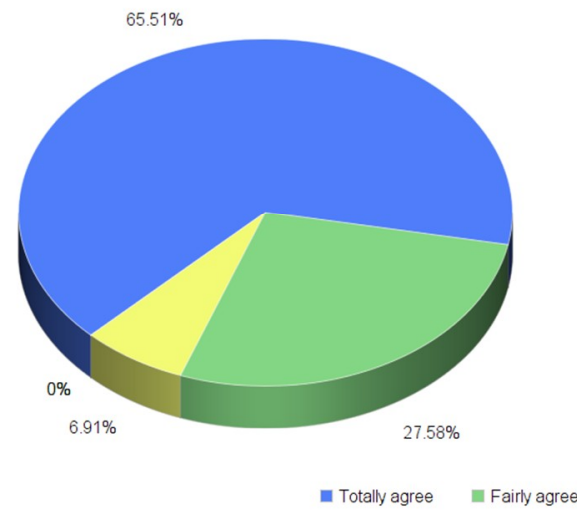

(a)
Ease of students to memorize content through AR

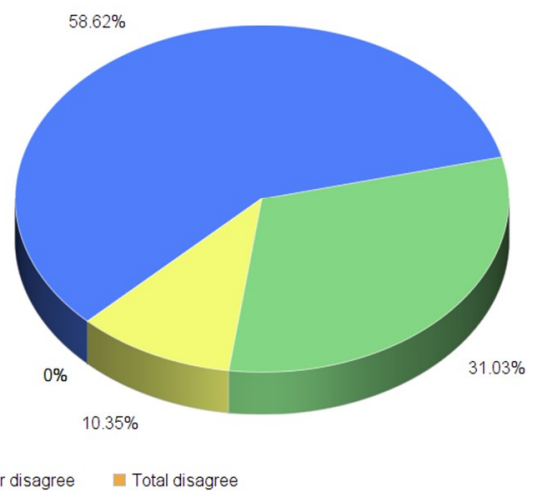

(b)

Figure 6. (a) Interest of students in learning through AR; (b) Ease with which students memorize content through AR.

Figure $6 \mathrm{~b}$ shows students' opinions about the ease of memorizing content through AR. Of the total, $58.62 \%$ of students strongly agree that memorizing highly visual content through AR is easy, and $31.03 \%$ merely agree with the statement. None of the students disagreed or strongly disagreed with this statement. This result reveals that the use of AR tools was useful for students to understand and memorize the content of the learning unit "Energy and its transformation" in a more effective way.

\section{Discussion}

Based on an analysis of the data on the effectiveness of learning through augmented environments, the written tests, and the Likert scale questionnaire, it can be affirmed that the integration of AR in the above mentioned learning unit had significant effects on the learning of the associated content.

First, the written test scores of students who followed a traditional teaching method were significantly lower than the scores of students who had used AR technology. Second, the use of AR in the classroom provided more meaningful learning for students with below-average performance than for high-performing students. The main cause of this disparity would be that the scores of high performing students have limited room for improvement. These data, as part of a broader set of indicators for the Education for Sustainable Development (ESD), serve to promote the comparison of student performance, monitoring, and data collection $[50,51]$, in addition to promoting the processes of benchmarking and promoting access to OER through ICT.

However, representing student learning improvements by a written test as an assessment tool may not be appropriate, especially when the main objective of AR technology is to help students develop problem-solving and exploration-based skills in research rather than cognitive memorization. AR technology provides a new cognitive method and it is hoped that through visualization and interaction with the medium, it will have a more lasting effect on the memorization of content by students [44-47].

We are aware that there are still barriers to the equal access to ICT, which cannot be overcome simply by technologies such as AR. We urge that in national plans to fulfill SDG goals, specific objectives to bring about equal access to and use of ICT be supported by programs with sufficient funding to ensure that groups that are socially or economically disadvantaged are not excluded. 
National policies and strategies in the field of ICT should concentrate on its potential and ensure that institutions and educational programs have adequate resources (through Open Educative Resources), and that a sufficient number of teachers qualified in ICT be available for implementation.

Lastly, from a social point of view, it is the governments of countries that should value practices that encourage real and durable sustainable development. The main aim of the UNESCO SDG4-Education 2030 Commission is to formulate recommendations for the educational community concerning the priorities and key measures necessary to fulfil the objectives set out, follow and encourage adequate funding for the same, and coordinate activities that favor the execution of SDG4.

\section{Conclusions}

As regards the usability of AR tools in the classroom, it is clearly a user-friendly technology, with an intuitive interface and a high degree of interactivity. In general, AR technology provides for the integration of proactive learning in the classroom, improving assimilation and access to content. However, mention should be made of the difficulty that the production of augmented materials entails for a large part of the teaching profession, possibly due to the lack of initial training in practical applications with ICT. Whatever the case, in reality there is no such difficulty, simply a lack of knowledge, because the production of augmented materials is systematic and sequential.

Therefore, research in ICT towards Education for Sustainable Development should be considered as one of the key disciplines in education, especially in the field of continuing education for teachers [52]. Numerous studies [53-56] indicate the importance of strengthening ESD within teacher training competences, and it is considered essential that teachers carry out training and lifelong learning activities. They should be offered continuous support and be provided with the incentives and professional motivation needed to promote the use of ICT with the aim of increasing the quality of learning within the framework of ESD.

It is worth highlighting the relevant role of ICT as a strategy in the sustainable development of society in favor of quality and the relevance of learning. For this, we must prioritize inclusive access to digital devices and resources, especially through Open Educational Resources (OER) as in the case of the augmented materials developed for this research. In this sense, educational administrations should support research and pilot studies to take advantage of emerging technologies such as AR, in order to transform education systems, make access to learning opportunities more equitable, and facilitate the provision of intelligent, individualized, and adapted learning services [57].

$\mathrm{AR}$ is a technology that for the reasons we have seen is beginning to be introduced into the education system. As an educational technology, if applied in an appropriate way, together with a contextualized methodology, it can be very useful not only to facilitate the teaching-learning process, but also to make activities more interactive, motivating, and interesting.

Likewise, AR technology favors the elimination of barriers for those with special educational needs. This leads us to consider the need to continue research and support this technology, which, if used in an appropriate way, will provide the possibility of improving the skills and access to information of all people. AR can help achieve sustainable development through the SDG 4, one of the goals of which focuses on "ensuring that all students acquire the knowledge and skills necessary to promote sustainable development" [2-5].

Finally, it should be noted that mobile devices have become the main tool for instantaneously accessing information in different formats, and their use throughout the world is expanding rapidly [42,43]; this fact, together with AR technology, combine to form a binomial that will help guarantee an inclusive education process, seeking equality and quality and facilitating learning throughout life. In short, an inseparable binomial to guarantee sustainable development to meet the 2030 horizon.

Author Contributions: Conceptualization, F.d.C.V. and G.M.M.; Methodology, F.d.C.V.; Software, G.M.M.; Validation, F.d.C.V. and G.M.M.; Formal Analysis, G.M.M.; Investigation, F.d.C.V. and G.M.M.; Resources, G.M.M.; Data Curation, F.d.C.V.; Writing-Original Draft Preparation, G.M.M.; Writing-Review \& Editing, F.d.C.V.; Visualization, G.M.M.; Supervision, F.d.C.V.; Project Administration, F.d.C.V.; Funding Acquisition, F.d.C.V. 
Funding: This research received no external funding.

Acknowledgments: We would like to thank all the anonymous reviewers for their valuable comments and suggestions which have helped improve this paper. We would also thank the Editors and the Editorial Office for their diligence.

Conflicts of Interest: The authors declare no conflict of interest.

\section{References}

1. Haberman, M. The pedagogy of poverty versus good teaching. Phi Delta Kappan 2010, 2, 81-87. [CrossRef]

2. United Nations Educational, Scientific and Cultural Organization (UNESCO). Guidelines for Inclusion: Ensuring Access to Education for All; UNESCO Publishing: Paris, France, 2005. Available online: http: / / unesdoc.unesco.org/images/0026/002651/265142e.pdf (accessed on 18 June 2018).

3. Leicht, A.; Heiss, J.; Byun, W.J. Issues and Trends in Education for Sustainable Development; UNESCO Publishing: Paris, France, 2018. Available online: http://unesdoc.unesco.org/images/0026/002614/261445e.pdf (accessed on 15 June 2018).

4. United Nations Educational, Scientific and Cultural Organization (UNESCO). UNESCO Roadmap for Implementing the Global Action Programme on Education for Sustainable Development; UNESCO Publishing: Paris, France, 2014. Available online: http:/ / unesdoc.unesco.org/images/0023/002305/230514e.pdf (accessed on 18 June 2018).

5. United Nations Educational, Scientific and Cultural Organization (UNESCO). UNESCO Education for Sustainable Development Goals; UNESCO Publishing: Paris, France, 2017. Available online: http:/ / unesdoc. unesco.org/images/0024/002474/247444e.pdf (accessed on 18 June 2018).

6. United Nations (UN). Report of the World Commission on Environment and Development: Our Common Future; United Nations: New York, NY, USA, 1987; ISBN 9780192820808.

7. United Nations Educational, Scientific and Cultural Organization (UNESCO). A Human Rights-Based Approach to Education; UNESCO Publishing: Paris, France, 2017. Available online: http:/ / unesdoc.unesco.org/images / 0015/001548/154861e.pdf (accessed on 18 June 2018).

8. United Nations Educational, Scientific and Cultural Organization (UNESCO). UNESCO Education Strategy 2014-2021; UNESCO Publishing: Paris, France, 2014. Available online: http:/ / unesdoc.unesco.org/images/ 0023/002312/231288e.pdf (accessed on 18 June 2018).

9. Thomazet, S. From Integration to Inclusive Education: Does Changing the Terms Improve Practice? Int. J. Incl. Educ. 2009, 13, 553-563. [CrossRef]

10. Escudero, J.M.; Martínez, B. Educación inclusiva y cambio escolar. Revista Iberoamericana de Educación 2011, $55,85-105$.

11. Jabareen, Y. Towards a Sustainability Education Framework: Challenges, Concepts and Strategies-The Contribution from Urban Planning Perspectives. Sustainability 2012, 4, 2247-2269. [CrossRef]

12. United Nations (UN). The Millennium Development Goals: 2015 Report; United Nations: New York, NY, USA, 2015. Available online: http://www.un.org/millenniumgoals/2015_MDG_Report/pdf/MDG\%202015\% 20rev\%20(July\%201).pdf (accessed on 18 June 2018).

13. United Nations Educational, Scientific and Cultural Organization (UNESCO). Education for All 2000-2015: Achievements and Challenges; UNESCO Publishing: Paris, France, 2005. Available online: http:/ / unesdoc. unesco.org/images/0023/002322/232205e.pdf (accessed on 18 June 2018).

14. United Nations Educational, Scientific and Cultural Organization (UNESCO). Education 2030: Incheon Declaration; UNESCO Publishing: Paris, France, 2015. Available online: http:/ / unesdoc.unesco.org/images / 0024/002456/245656e.pdf (accessed on 18 June 2018).

15. United Nations (UN). The Sustainable Development Goals Report 2016; United Nations: New York, NY, USA, 2016; ISBN 978-992-1-101340-5.

16. Crespo, B.; Míguez-Álvarez, C.; Arce, M.E.; Cuevas, M.; Míguez, J.L. The Sustainable Development Goals: An Experience on Higher Education. Sustainability 2017, 9, 1353. [CrossRef]

17. Caudell, T.P.; Mizell, D.W. Augmented reality: An application of heads-up display technology to manual manufacturing processes. In Proceedings of the Twenty-Fifth Hawaii International Conference on System Sciences, Kauai, HI, USA, 7-10 January 1992; Volume 2, pp. 659-669. 
18. Milgram, P.; Takemura, H.; Utsumi, A.; Kishino, F. Augmented Reality: A class of displays on the realityvirtuality continuum. Telemanipulator Telepresence Technol. 1995, 2351, 282-292.

19. Azuma, R. A Survey of Augmented Reality. Presence Teleoper. Virtual Environ. 1997, 6, 335-385. [CrossRef]

20. Zhou, F.; Duh, H.; Billinghurst, M. Trends in augmented reality tracking, interaction and display: A review of ten years of ISMAR. In Proceedings of the 7th IEEE/ACM International Symposium on Mixed and Augmented Reality, Cambridge, MA, USA, 15-18 September 2008; pp. 193-202.

21. Lee, K. Augmented Reality in Education and Training. TechTrends 2012, 56, 13-21. [CrossRef]

22. Prendes, C. Realidad aumentada y educación: Análisis de experiencias prácticas. Pixel-Bit. Revista de Medios y Educación 2015, 46, 187-203.

23. Schmalstieg, D.; Höllerer, T. Augmented Reality: Principles and Practice; Addison-Wesley: Boston, MA, USA, 2016; ISBN 978-0321883575.

24. Chang, G.; Morreale, P.; Medicherla, P. Applications of augmented reality systems in education. In Proceedings of the Society for Information Technology \& Teacher Education International Conference, San Diego, CA, USA, 29 March 2010; Gibson, D., Dodge, B., Eds.; AACE: Chesapeake, VA, USA, 2010; pp. 1380-1385.

25. Baldiris, S.; Duque, N.; Salas, D.; Bernal, J.; Fabregat, R.; Mendoza, R.; Puerta, Y.; Puello, J.; Solano, I.; Martínez, L. Recursos Educativos Aumentados. Una Oportunidad para la Inclusión; Sello Editorial Tecnológico Comfenalco: Cartagena de las Indias, Colombia, 2016; ISBN 978-958-59656-0-7.

26. Olesky, T.; Wnuk, A. Augmented places: An impact of embodied historical experience on attitudes towards places. Comput. Hum. Behav. 2016, 57, 11-16.

27. Jeong, B.; Yoon, J. Competitive Intelligence Analysis of Augmented Reality Technology Using Patent Information. Sustainability 2017, 9, 497. [CrossRef]

28. Dunleavy, M.; Dede, C.; Mitchell, R. Affordances and Limitations of Immersive Participatory Augmented Reality Simulations for Teaching and Learning. J. Sci. Educ. Technol. 2008, 18, 7-22. [CrossRef]

29. Martínez-Graña, A.M.; González-Delgado, J.; Pallarés, S.; Goy, J.L.; Llovera, J.C. 3D Virtual Itinerary for Education Using Google Earth as a Tool for the Recovery of the Geological Heritage of Natural Areas: Application in the “Las Batuecas Valley" Nature Park (Salamanca, Spain). Sustainability 2014, 6, 8567-8591. [CrossRef]

30. Del Cerro, F.; Morales, G. Augmented Reality as a tool for improving spatial intelligence in secondary education students. Revista de Educación a Distancia 2017, 54, 5.

31. Marshall, C. Reading and interactivity in the digital library: Creating an experience that transcends paper. In Proceedings of the CLIR/Kanazawa Institute of Technology Roundtable, Kanazawa, Japan, 28 October 2005; Volume 5, pp. 1-20.

32. Billinghurst, M.; Kato, H.; Poupyrey, I. The magicbook-moving seamlessly between reality and virtuality. IEEE Comput. Graph. Appl. 2001, 21, 6-8.

33. Jonhson, L.; Levine, A.; Smith, R.; Stone, S. The 2010 Horizon Report; New Media Consortium: Austin, TX, USA, 2010; ISBN 978-0-9825-3343-7.

34. Roussos, M.; Jhonson, A.; Moher, T.; Leigh, J.; Vasilakis, C.; Barnes, C. Learning and Building Together in an Immersive Virtual World. Presence Teleoper. Virtual Environ. 1999, 8, 247-263. [CrossRef]

35. Ballew, M.T.; Omoto, A.M.; Winter, P.L. Using Web 2.0 and Social Media Technologies to Foster Proenvironmental Action. Sustainability 2015, 7, 10620-10648. [CrossRef]

36. Kiyokawa, K.; Billinghurst, M.; Hayes, S.; Gupta, A.; Sannohe, Y.; Kato, H. Communication Behaviors of Co-Located Users in Collaborative AR Interfaces. In IEEE and ACM International Symposium on Mixed and Augmented Reality; IEEE Computer Society Press: Darmstadt, Germany, 2002; pp. 139-148.

37. United Nations Educational, Scientific and Cultural Organization (UNESCO). Policy Guidelines for Mobile Learning; UNESCO Publishing: Paris, France, 2013. Available online: http:/ / unesdoc.unesco.org/images/ 0021/002196/219641E.pdf (accessed on 18 June 2018).

38. Billinghurst, M. Augmented reality in education. New Horiz. Learn. 2002, 12, 5.

39. ICT in Education Prize. Available online: https://en.unesco.org/themes/ict-education/ict-education-prize (accessed on 18 June 2018).

40. Fambona, J.; Pascual, M.Á.; Madeira, M.F. Realidad aumentada una evolución de las aplicaciones de los dispositivos móviles. Pixel-Bit. Revista de Medios y Educación 2012, 41, 197-210. 
41. Valero, M. Tecnologías para la Educación Inclusiva: De la integración a la interacción. In 25 Años de Integración Escolar en España: Tecnología e Inclusión en el Ámbito Educativo, Laboral y Comunitario; Arnaiz, P., Hurtado, M.D., Soto, F.J., Eds.; Consejería de Educación, Formación y Empleo: Murcia, Spain, 2010; pp. 1-5. ISBN 978-984-693-1781-5.

42. StatCounter GlobalStats. Mobile and Tablet Internet Usage Excedes Desktop for First Time Worldwide. Available online: http:/ /gs.statcounter.com/press/mobile-and-tablet-internet-usage-exceeds-desktop-forfirst-time-worldwide (accessed on 18 June 2018).

43. Adams Becker, S.; Cummins, M.; Davis, A.; Freeman, A.; Hall Giesinger, C.; Ananthanarayanan, V. The NMC Horizon Report: 2017 Higher Education Edition; New Media Consortium: Austin, TX, USA, 2017; ISBN 978-0-9977215-7-7.

44. Campillo, E.; Ricarte, J.J.; Ros, L.; Nieto, M.; Latorre, J.M. Effects of the Visual and Auditory Components of a Brief Mindfulness Intervention on Mood State and on Visual and Auditory Attention and Memory Task Performance. Curr. Psychol. 2018, 37, 357-365. [CrossRef]

45. Steding, J.; Holthoff-Detto, V. Kognitive Reserve und Potenzial im Alter. DNP Der Neurologe und Psychiater 2016, 17, 50-58. [CrossRef]

46. Rönnlund, M.; Sundström, A.; Pudas, S. Midlife level and 15-year changes in general cognitive ability in a sample of men: The role of education, early adult ability, BMI, and pulse pressure. Inelligence 2017, 61, 78-84. [CrossRef]

47. Lenehan, M.E.; Summers, M.J.; Saunders, N.L.; Summers, J.J.; Vickers, J.C. Relationship between education and age-related cognitive decline: A review of recent research. Psychogeriatrics 2015, 15, 154-162. [CrossRef] [PubMed]

48. Kaufmann, H.; Schmalsteig, D. Mathematics and geometry education with collaborative augmented reality. In Proceedings of the ACM SIGGRAH 2002 Conference Abstract and Applications, San Antonio, TX, USA, 21-26 July 2002; pp. 37-41.

49. Layar. Available online: http:/ / www.layar.com (accessed on 18 June 2018).

50. Tilbury, D.; Janousek, S.; Elias, D.; Bacha, J. Asia-Pacific Guidelines for the Development of National ESD Indicators; UNESCO: Bangkok, Thailand, 2017. Available online: http:/ / unesdoc.unesco.org/images/0015/001552/ 155283e.pdf (accessed on 18 June 2018).

51. Zou, Y.; Zhao, W.; Mason, R.; Li, M. Comparing Sustainable Universities between the United States and China: Cases of Indiana University and Tsinghua University. Sustainability 2015, 7, 11799-11817. [CrossRef]

52. Waltner, E.-M.; Rieß, W.; Brock, A. Development of an ESD Indicator for Teacher Training and the National Monitoring for ESD Implementation in Germany. Sustainability 2018, 10, 2508. [CrossRef]

53. Ketschau, T.J. A Conceptual Framework for the Integration of Corporate Social Responsibility and Human Resource Development Based on Lifelong Learning. Sustainability 2017, 9, 1545. [CrossRef]

54. Radomska, J. The Concept of Sustainable Strategy Implementation. Sustainability 2015, 7, 15847-15856. [CrossRef]

55. Fleacă, E.; Fleacă, B.; Maiduc, S. Aligning Strategy with Sustainable Development Goals (SDGs): Process Scoping Diagram for Entrepreneurial Higher Education Institutions (HEIs). Sustainability 2018, 10, 1032. [CrossRef]

56. Bertschy, F.; Künzli, C.; Lehmann, M. Teachers' Competencies for the Implementation of Educational Offers in the Field of Education for Sustainable Development. Sustainability 2013, 5, 5067-5080. [CrossRef]

57. United Nations Educational, Scientific and Cultural Organization (UNESCO). UNESCO International Forum on ICT and Education 2030, 2017 Quingdao Statement: Strategies for Leveraging ICT to Achieve Education 2030; UNESCO Publishing: Paris, France, 2017. Available online: http://unesdoc.unesco.org/images/0025/ 002530/253061m.pdf (accessed on 18 June 2018).

(C) 2018 by the authors. Licensee MDPI, Basel, Switzerland. This article is an open access article distributed under the terms and conditions of the Creative Commons Attribution (CC BY) license (http://creativecommons.org/licenses/by/4.0/). 